\title{
DNA-树状聚脂肪醚杂化体的合成及组装性能研究
}

\author{
赵智勇 ${ }^{a, c}$ 吴芬 ${ }^{a}$ 杨忠强 $*, b \quad$ 刘冬生 ${ }^{b}$ 范青华 $*, a$ \\ ( ${ }^{a}$ 中国科学院化学研究所分子识别与功能重点实验室 北京分子科学国家实验室 北京 100190) \\ ( ${ }^{b}$ 清华大学化学系 有机光电子与分子工程教育部重点实验室 北京 100084) \\ ( ${ }^{c}$ 中国科学院大学 北京 100049)
}

\begin{abstract}
摘要 通过半固相合成方法得到一类新型的具柔性骨架的树状聚脂肪醚(PMDC)与 DNA 的嵌段共聚物, 也称为 DNA树状聚脂肪醚杂化体, 其结构通过了 MALDI-TOF MS、HPLC 和聚丙烯酰胺凝胶电泳(PAGE)表征. 研究证明, 通过调 节 DNA-树状聚脂肪醚杂化体的结构和组装的溶剂体系，可以得到各种不同的有序聚集体(球形胶束、纳米纤维等), 这 些组装形貌均通过透射电镜(TEM)、原子力显微镜(AFM)和动态光散射(DLS)进行表征; 荧光包裹实验和 DNA 互补配 对实验不仅证明了疏水树状聚脂肪醚位于组装体内核、DNA 处于外壳的组装机理，也说明这类 DNA-树状聚脂肪醚杂 化体将在疏水药物运输和纳米技术等领域具有潜在的应用.
\end{abstract}

关键词 DNA-树状分子; 两亲分子; 自组装; 球形胶束; 纤维

\section{Synthesis and Self-Assembly of DNA-Aliphatic Polyether Dendron Hybrids}

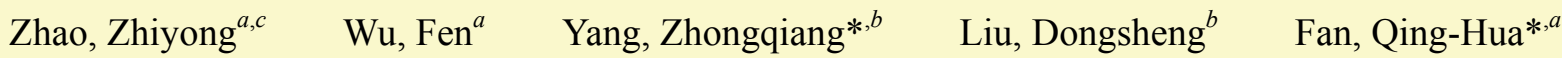 \\ ( ${ }^{a}$ Beijing National Laboratory for Molecular Sciences (BNLMS), CAS Key Laboratory of Molecular Recognition and \\ Function, Institute of Chemistry, Chinese Academy of Sciences (CAS), Beijing 100190, China) \\ $\left({ }^{b}\right.$ Key Laboratory of Organic Optoelectronics \& Molecular Engineering of the Ministry of Education, \\ Department of Chemistry, Tsinghua University, Beijing 100084, China) \\ ( ${ }^{c}$ University of Chinese Academy of Sciences, Beijing 100049, China)
}

\begin{abstract}
A new kind of amphiphilic DNA-aliphatic polyether dendron hybrids consisting of a flexible hydrophobic polyether dendron and a single stranded DNA are synthesized, which are characterized by MALDI-TOF mass spectroscopy, HPLC and polyacrylamide gel electrophoresis (PAGE). In aqueous solution, as DNA length shortens from 24 mer to 18 mer, to $12 \mathrm{mer}$, to $6 \mathrm{mer}$, the hydrophilic DNA content in the DNA-aliphatic polyether dendron hybrid decreases, the morphology of the aggregates change from spherical micelles to nanofibers, and to irregular clusters. These different assemblies from DNA-aliphatic polyether dendron hybrids in aqueous solution are depended on the hydrophobic/hydrophilic ratio between the polyether dendron skeleton and DNA strand. However, when adding 1/10 $(V / V)$ organic solvents such as dichloromethane (DCM), diethyl ether (EtOEt) or tetrahydrofuran (THF) into aqueous solution and after the assembling process that the sample solution is heated to $90{ }^{\circ} \mathrm{C}$ for $30 \mathrm{~min}$ and subsequently cooled to room temperature overnight, the third generation dendron conjugated 18 mer DNA hybrid could assemble into nanofibers. Meanwhile, in the $\mathrm{THF} / \mathrm{H}_{2} \mathrm{O}(1: 10, V / V)$ mixed solvents, with the same assembling process, as different dendron generations (the second or third generation) and different DNA lengths ( 6 mer, 12 mer, 18 mer or 24 mer) in the hybrids, all these hybrids could assemble into long nanofibers. The assembled structures have been characterized by transmission electron microscopy (TEM), atomic force microscope (AFM), dynamic light scattering (DLS) and fluorescent experiments. Subsequently, we verified the assembling mechanism that the spherical micelles and nanofibers contain a hydrophobic dendron core and a hydrophilic DNA shell by hydrophobic fluorescent molecule Nile Red encapsulation experiment and precise DNA hybridization to load gold nanoparticles at a size of 10 $\mathrm{nm}$. The hybridization property of DNA at the shell associated with the encapsulation ability of dendron at the inner core indicated the potential application in gene or drug delivery and nanotechnology.
\end{abstract}

Keywords DNA-dendron; amphiphile; self-assembly; spherical micelle; nanofiber

\section{1 引言}

两亲性嵌段共聚物在固相或溶液中能组装成多种 形貌, 如球形胶束, 棒状胶束, 层状结构和囊泡等. 通
过控制其单体的化学性质、嵌段链长、亲疏水比例以及 外界环境因素(溶剂、温度、酸碱等)等，可精确调控这 些组装形貌 ${ }^{[1]}$. 近年来, 将生物大分子取代有机高分子 嵌段, 所得的生物有机两嵌段杂化结构也成为一类研究

*E-mail: fanqh@iccas.ac.cn, Tel.: 010-62554472; zyang@tsinghua.edu.cn, Tel.: 010-62798297

Received January 17, 2013; published March 1, 2013.

Supporting information for this article is available free of charge via the Internet at http://sioc-journal.cn.

Project supported by the National Natural Science Foundation of China (Nos. 21232008, 21174077, 91027046) and 973 Program (No. 2013CB932800).

项目受国家自然科学基金(Nos. 21232008, 21174077, 91027046)和 973 项目(No. 2013CB932800)资助. 
热点，这类杂化材料不仅能在溶液中进行组装，同时还 能保持生物大分子的生物学特性, 在纳米技术和药物运 输等方面具有广泛的应用前景 ${ }^{[2]}$, 比如多肽一有机高分 子共聚物 ${ }^{[3]}$. 但有关核酸与合成高分子结合的核酸-合 成高分子嵌段共聚物(DNA Block Copolymers, DBCs)的 研究报道还较少 ${ }^{[4]}$. 在这类 DNA 嵌段共聚物中, 合成高 分子可任意选择, 可改变单体性质及链长等, 可以是水 溶性高分子如聚赖氨酸 ${ }^{[5]}$, 也可以是疏水性高分子如聚 环氧丙烷 ${ }^{[6]}$ 或聚苯乙烯 ${ }^{[7]}$ 等; 而 DNA 作为构筑纳米组装 体的结构单元, 其具有可程序设计、序列精确识别等特 点 $^{[8]}$, 从而使其组装体具有形貌可控及温度响应、酶响 应等性质. 这类 DNA 嵌段共聚物可以作为基因或 DNA 转移的材料, 用于生物材料的纯化 ${ }^{[9]}$ 和 DNA 检测 ${ }^{[10]}$ 等 领域.

树状大分子，与线型聚合物相比，它是一类高度支 化、具有树枝状三维结构的单分散大分子, 单分子尺度 在纳米级, 其结构有着良好的几何对称性, 而且分子的 体积和形状可以得到精确的控制. 作为一类新型结构的 大分子, 近 20 年来在生物、医药、催化和光电材料等领 域受到广泛关注 ${ }^{[11]}$.

将这样一类结构精美明确、分散单一的树状大分子 与 DNA 结合, 将得到一类新的超分子构筑单元-DNA树状分子嵌段共聚物, 其组装可能得到具有结构可控和 功能多样化的智能型软物质材料. 目前关于 DNA-树状 分子嵌段共聚物的合成的报道有几例 ${ }^{[12]}$, 但关于其在 水相组装是我们组开展了最早的研究, 即具刚性骨架的 强疏水性聚苠醚树状分子与亲水 DNA 的结合, 通过水 相添加有机溶剂控制其组装形貌 ${ }^{[13]}$. 本文中, 我们选用
具柔性骨架且弱疏水性的聚脂肪醚树状分子(PMDC), 将其与不同 DNA 序列结合, 研究其在不同溶剂中的组 装行为及进一步的功能化应用, 为研究树状分子骨架对 杂化体组装的影响提供一定的理论依据.

\section{2 结果与讨论}

\subsection{DNA-树枝状聚脂肪醚杂化体的合成}

DNA-树枝状聚脂肪醚杂化体的合成，如图 1 所示. 首先根据 Fréchet 等 ${ }^{[14]}$ 的相关报道, 用收敛法制得了二 代和三代的脂肪族聚醚型树枝分子 (G2-ol 和 G3-ol). 接 着基于我们的报道方法 ${ }^{[13]}$ ，核心为羟基的树枝状聚脂 肪醚 $(\mathrm{Gn}-\mathrm{ol})$ 与 2-氧乙基- $N, N$-二异丙基氯代亚磷酰胺反 应得亚磷酰胺活化试剂(Gn-P), 然后与负载于可控孔度 玻璃 $(\mathrm{CPG})$ 小球上的 DNA 进行半固相合成 ${ }^{[7]}$ ，依次通过 四唑的活化、碘水氧化、浓氨水的脱保护基团以及切掉 CPG 小球, 最终可得产物. 我们选用四种不同长度的 DNA 序列(DNA6, DNA12，DNA18，DNA24，其中数字 代表序列的碱基数)与三代树状分子反应，相应得到四 种产物, 分别记为 G3-DNA6, G3-DNA12, G3-DNA18 和 G3-DNA24. 同时还合成了二代树状聚脂肪醚与 DNA18 的杂化产物, 记为 G2-DNA18. 这五种产物均通过 HPLC 纯化, 聚丙烯酰胺凝胶电泳(PAGE)的表征(图 2) 以及 MALDI-TOF MS 表征(表 1), 测量值与计算值相符, 且产率较好，均在 $40 \% \sim 56 \%$ 之间.

\subsection{DNA-树枝状聚脂肪醚杂化体的组装}

关于 DNA 与树枝状分子的结合, 我们组之前报道 了 DNA 与树状聚茮醚杂化体的组装行为研究 ${ }^{[13,15]}$, 发

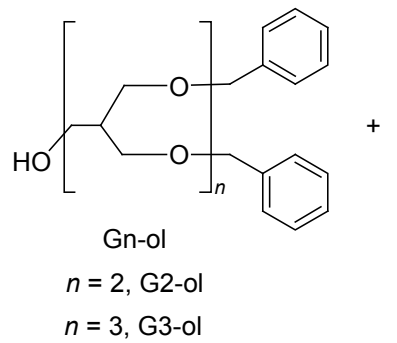<smiles>CC(C)N(C(C)C)P(Cl)OCCC#N</smiles>
DIPEA, THF<smiles>CC(C)N(C(C)C)P(OCCC#N)OC(C)(COC(C)(C)c1ccccc1)C(C)(C)c1ccccc1</smiles>
$n=2, \mathrm{G} 2-\mathrm{P}$ $n=3, \mathrm{G} 3-\mathrm{P}$

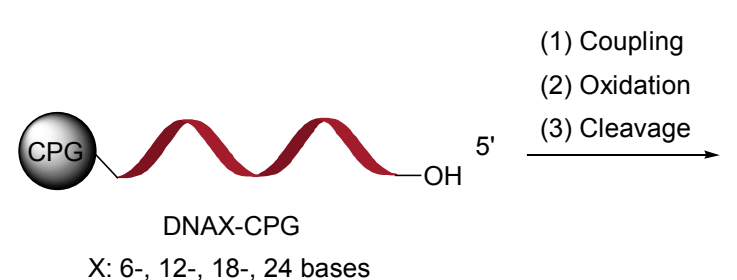

$\mathrm{X}$ : 6-, 12-, 18-, 24 bases

DNAX:

DNA6: 5'-TTT TTT-3'

DNA12: 5'-TTT ACT CAT CTT-3'

DNA18: 5'-TTT TAC ACA TCT ACT TCA-3'

DNA24: 5'-CCC TAA CCC TAA CCC TAA CCC TTT-3'

图 1 DNA-树枝状聚脂肪醚杂化体的合成路线和不同 DNA 序列

Figure 1 The synthesis route of DNA-dendron hybrids and four different DNA sequences 


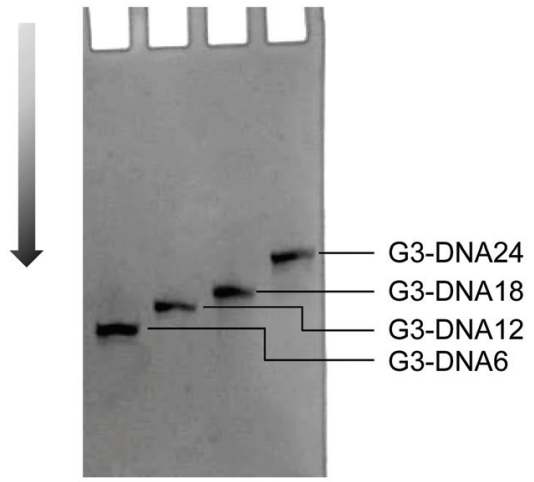

图 2 四种不同 DNA-树枝状聚脂肪醚杂化体的变性聚丙烯酰胺凝胶 电泳 $(20 \%)$ 表征

Figure 2 Denaturing polyacrylamide gel electrophoresis (20\%, Acr/ Bis $=19: 1$ ) analysis of four different DNA-dendron hybrids

表 1 DNA-树枝状聚脂肪醚杂化体的 MALDI-TOF MS 表征及产率 Table 1 MALDI-TOF MS and isolated yield of DNA-Dendron hybrids

\begin{tabular}{lclcc}
\hline \multicolumn{1}{c}{ Sample } & Calculated & \multicolumn{1}{c}{ Found } & $\begin{array}{c}\text { Error } \\
\text { (Calcd-Found) }\end{array}$ & Yield $^{a}$ \\
\hline G2-DNA18 & 6059 & 6066 & -7 & $46 \%$ \\
G3-DNA6 & 3125 & $3148(+\mathrm{Na})$ & 1 & $43 \%$ \\
G3-DNA12 & 4922 & 4925 & -3 & $56 \%$ \\
G3-DNA18 & 6995 & 6997 & -2 & $48 \%$ \\
G3-DNA24 & 8475 & 8479 & -4 & $40 \%$ \\
\hline
\end{tabular}

${ }^{a}$ 以具有反应活性的 DNA 量为计算标准的分离产率.

现 DNA-聚茮醚杂化体只有在含有机溶剂 [二氯甲烷 (DCM)，四氢呋喃(THF)或乙腈 $\left.\left(\mathrm{CH}_{3} \mathrm{CN}\right)\right]$ 的情况下能组 装成均一纳米纤维, 推测可能由于树状聚苠醚分子的熔 点太高 $\left(114{ }^{\circ} \mathrm{C}\right)$, 在不良溶剂即纯水中被迅速冻结, 无 法进行有序组装, 所以添加树状分子的良溶剂, 有利于 两亲分子的组装, 从而形成纳米纤维. 而此体系中的树 状聚脂肪醚 $\mathrm{G} 3-\mathrm{ol}$ 的玻璃化转变温度 $T_{\mathrm{g}}$ 为 $-39{ }^{\circ} \mathrm{C}^{[16]}$, 室温下呈液态，在水溶液中不会被立即冻结. 而且其外 围苯环使得树状分子具有一定的疏水性, 柔性脂肪醚骨 架又具有一定的亲水性, 再加上 DNA 的亲水性质, 则 DNA-树状聚脂肪醚杂化体可能具有不一样的组装行为.

\subsection{1 纯水相的组装行为}

正因为树状聚脂肪醚的柔性骨架和疏水苯环的两 重作用, 我们首先研究了 DNA-树状聚脂肪醚杂化体在 纯水中的组装行为. 以 G3-DNA18 为代表, 首先通过对 疏水分子尼罗红的包裹, 利用荧光探针法 ${ }^{[17]}$ 测定了其 临界胶束浓度 $(\mathrm{CMC})$ 为 $17 \mu \mathrm{mol} / \mathrm{L}$ (见 Figure S2, 支持信 息). 随后通过在水相进行组装, 利用透射电镜(TEM)观 察, 其组装为直径 $20 \mathrm{~nm}$ 左右的球形胶束(图 3A). 动态 光散射(DLS)的数据显示其直径为 (16.3 \pm 2.1$) \mathrm{nm}$ (图 3B), 与透射电镜的数据相符, 约为 G3-DNA18 分子尺寸 $(8.7$ $\mathrm{nm}$ )的两倍. 其中亲水的 DNA18 长 $7.7 \mathrm{~nm}$, 考虑其单链 且在水相中呈伸展状态 ${ }^{[18]}$; 疏水部分 G3-PMDC 根据文 献报道其尺寸约为 $1 \mathrm{~nm}^{[19]}$, 则理论上 G3-DNA18 分子
尺寸约为 $8.7 \mathrm{~nm}$. 由此推测, 球形胶束中疏水的树枝状 聚脂肪醚位于内核, 亲水的 DNA 链作为胶束外壳. 同 时这也证明了 G3-DNA18 能在纯水中进行组装, 不需要 有机溶剂的加入.
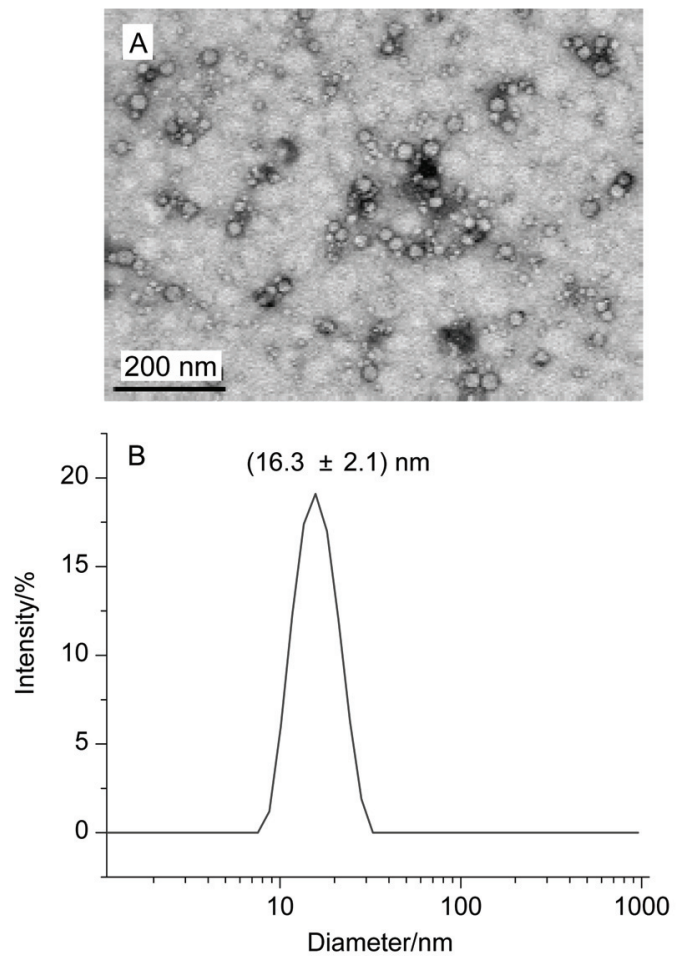

图 $340 \mu \mathrm{mol} / \mathrm{L}$ G3-DNA18 在纯水中的组装形貌. (A)透射电镜和(B) 动态光散射数据

Figure 3 TEM image (A) and DLS data (B) of $40 \mu \mathrm{mol} \cdot \mathrm{L}^{-1}$ G3-DNA18 assembled in aqueous solution

用同样的组装条件对 G2-DNA18, G3-DNA6, G3-DNA12 和 G3-DNA24 进行组装. 相同浓度 $(40$ $\left.\mu \mathrm{mol} \cdot \mathrm{L}^{-1}\right)$ 下, 发现 $\mathrm{G} 2$-DNA18 没有均一的组装形貌 (TEM 观察)，且 DLS 也没有测到组装体的尺寸，推测可 能由于 G2-DNA18 分子中的疏水片段较小, 疏水作用不 够强, 使得分子难以进行有序堆积. 通过 TEM 观察(见 Figure S3，支持信息), G3-DNA24 组装成 $20 \mathrm{~nm}$ 左右的 球形胶束; G3-DNA12 的组装体系中出现直径 $20 \mathrm{~nm}$ 左 右的纳米纤维，同时存在网络结构; G3-DNA6 组装为复 杂的三维网络结构 ${ }^{[20]}$. 这一结果充分说明了在纯水体 系中，随着杂化体中亲水 DNA 含量的减少，其组装形 貌由球形胶束变到纳米纤维, 最后形成三维网络结构. 与经典的嵌段聚合物的组装机理 ${ }^{[2]}$ 是相符的.

\subsection{2 混合溶剂中的组装行为}

以 G3-DNA18 为代表, 研究其在不同混合溶剂中的 组装行为. 结合树枝状聚脂肪醚在不同有机溶剂中的溶 解性, 分别选了 DCM、THF 和乙醚(EtOEt)三种有机溶 剂, 与水以体积比为 $1 / 10$ 进行研究. $100 \mu \mathrm{L}$ 的样品水溶 液中快速加入 $10 \mu \mathrm{L}$ 有机溶剂, 振荡离心后, 于 $90{ }^{\circ} \mathrm{C}$ 加 
热 $30 \mathrm{~min}$ 后, 自然冷却至室温, 放置过夜后测试. 通过 TEM 表征, 如图 4, 可以发现含 DCM 的混合溶剂中, G3-DNA18 组装成短粗的纳米纤维, 且伴随有小的球形 胶束的形成, 这是由于树枝状聚脂肪醚在 DCM 中的溶 解性不好, 导致产生不同聚集体; 而当加 EtOEt 或 THF 时, 均能组装得到直径为 $20 \mathrm{~nm}$ 左右的细长纤维. 考虑 到 EtOEt 的沸点较低, 容易挥发, 可能造成组装形貌的 不稳定, 因此选择了 $\mathrm{THF} / \mathrm{H}_{2} \mathrm{O}(1: 10, V / V)$ 为溶剂体系 展开组装研究.

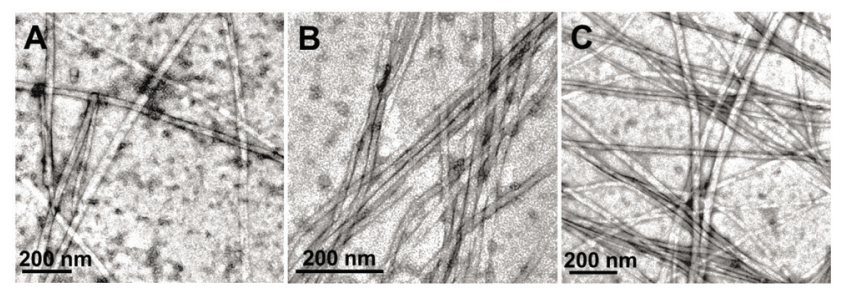

图 4 G3-DNA18 在不同溶剂中的组装形貌的透射电镜图

Figure 4 TEM images of G3-DNA18 assemblies at different solvents (A) $\mathrm{DCM} / \mathrm{H}_{2} \mathrm{O}(1: 10, V / V) ;$ (B) $\mathrm{EtOEt} / \mathrm{H}_{2} \mathrm{O}(1: 10, V / V)$; (C) $\mathrm{THF} / \mathrm{H}_{2} \mathrm{O}(1:$ $10, V / V)$

首先, 我们探讨了疏水树状分子结构对组装形貌的 影响, 利用 TEM 和 AFM 研究了 G2-DNA18 和 G3-DNA18 的组装, 从图 5 中, 我们发现, $100 \mu \mathrm{mol} / \mathrm{L}$ G2-DNA18 和 $40 \mu \mathrm{mol} / \mathrm{L}$ G3-DNA18 均能组装得到长十 几微米的纳米纤维, 其直径均为 $20 \mathrm{~nm}$ 左右(TEM 测试), 约为 G3-DNA18 分子尺寸 $(8.7 \mathrm{~nm})$ 的两倍. 由此推测,
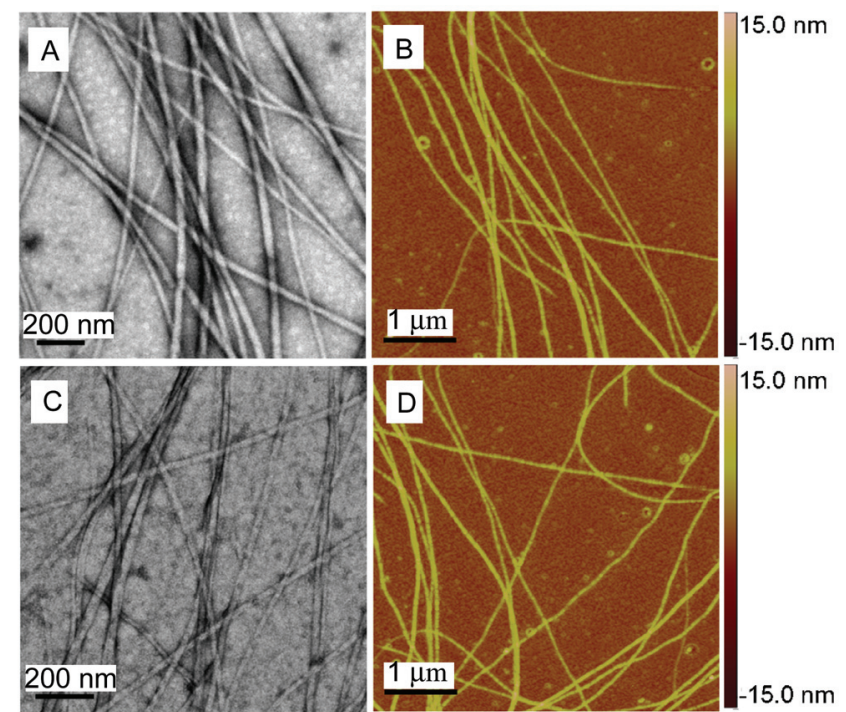

图 5 G2-DNA18 和 G3-DNA18 在 $\mathrm{THF} / \mathrm{H}_{2} \mathrm{O}(1: 10, V / V)$ 中组装的 TEM 和 AFM 图. A 和 B: 分别为 G2-DNA18 自组装成纳米纤维的 TEM 和 AFM; C 和 D: 分别为 G3-DNA18 自组装成纳米纤维的 TEM 和 AFM

Figure 5 Self-assembly morphologies of G2-DNA18 and G3-DNA18 in mixed solvent THF/ $\mathrm{H}_{2} \mathrm{O}(1: 10, V / V)$. A and B: TEM and AFM images of nanofibers assembled from G2-DNA18; C and D: TEM and AFM images of nanofibers assembled from G3-DNA18
纳米纤维的内核为疏水的树枝状聚脂肪醚，外围为亲水 的 DNA 链. 由于 G2-PMDC 的分子尺寸比 G3-PMDC 稍 小且不超过 $1 \mathrm{~nm}$, 固通过透射电镜观察, 其组装得到的 纤维直径也为 $20 \mathrm{~nm}$ 左右. 这些测得的 TEM 数据与理 论数据基本相符. 但在 AFM 测试中, G2-DNA18 组装的 纤维高度为 $(12.3 \pm 1.2) \mathrm{nm}, \mathrm{G} 3-\mathrm{DNA} 18$ 组装的纤维高度 为 $(13.4 \pm 1.1) \mathrm{nm}$, 均比计算的理论值小, 可能由于测试 过程中针尖的作用使得纤维坍塌, 从而使数据偏小. 这 些结果证明了在含有机溶剂的混合体系中, G2-DNA18 和 G3-DNA18 均能组装形成均一细长的纳米纤维, 且两 者直径没有很大差距.

随后，我们考察了亲水部分为不同长度 DNA 序列 对组装形貌的影响. 通过 TEM 观察(如图 6), 发现 G3-DNA6, G3-DNA12 和 G3-DNA24 均能组装成细长的 纳米纤维, 且随着 DNA 序列的变长, 相应组装纤维的 直径也变大, 这一结果说明在混合溶剂中, 随着亲水含 量的增加, 并没有改变其组装形貌. 在此研究体系中, 经典的嵌段聚合物的组装机理已经不适用, 相关的研究 也有报道 ${ }^{[22]}$.

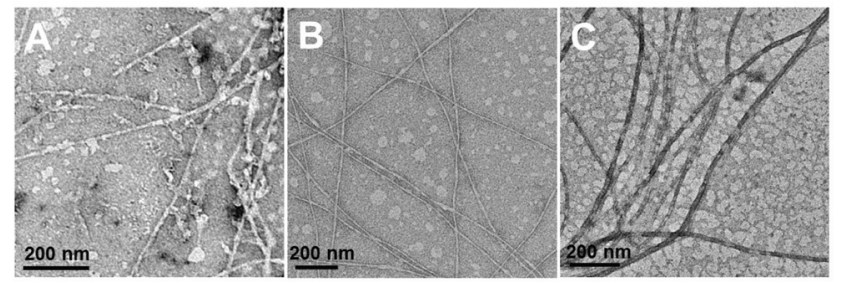

图 6 不同 DNA-dendron 在 $\mathrm{THF} / \mathrm{H}_{2} \mathrm{O}(1: 10, V / V)$ 中的组装行为的透 射电镜图

Figure 6 TEM images of different DNA-dendron hybrids assembled in mixed solvents $\mathrm{THF} / \mathrm{H}_{2} \mathrm{O}(1: 10, V / V)$

(A) G3-DNA6; (B) G3-DNA12; (C) G3-DNA24

\subsection{DNA-聚脂肪醚树状分子组装体的功能化研究}

我们以 G3-DNA18 体系为例, 在不同的溶剂体系中 组装得到不同的组装形貌，即球形胶束和纳米纤维，根 据组装体尺寸，推测其组装机理均为树枝状聚脂肪醚位 于核心，亲水的 DNA 链位于外围. 我们选用疏水分子 尼罗红，对其进行包裹实验，通过荧光光谱，如图 7A， 在纯水中, 当 $40 \mu \mathrm{mol} / \mathrm{L}$ 浓度时, 高于其 CMC (17 $\mu \mathrm{mol} / \mathrm{L})$, 发现在 $621 \mathrm{~nm}$ 处有明显的荧光发射峰; 而 2 $\mu \mathrm{mol} / \mathrm{L}$ 浓度时, 基本没有荧光发射, 这是由于低浓度时 没有组装体形成，不存在疏水的核，无法对疏水分子进 行包裹. 同时我们也利用荧光显微镜对混合溶剂中的组 装形貌进行了观察, 如图 7B, 发现能观察到细长的纤维. 这些实验都证实了我们之前推测的组装机理是合理正 确的，同时这些实验也为包裹疏水药物等提供了模型.

同时，我们利用组装体外围 DNA 序列具有精确的 互补识别特性，在其外围进行功能化修饰和负载. 首先, 将直径 $10 \mathrm{~nm}$ 的金纳米颗粒的表面修饰上 $5^{\prime}$ 端颈基修饰 的互补 DNA 序列(5'-TGA AGT AGA TGT GTA-3'), 将 

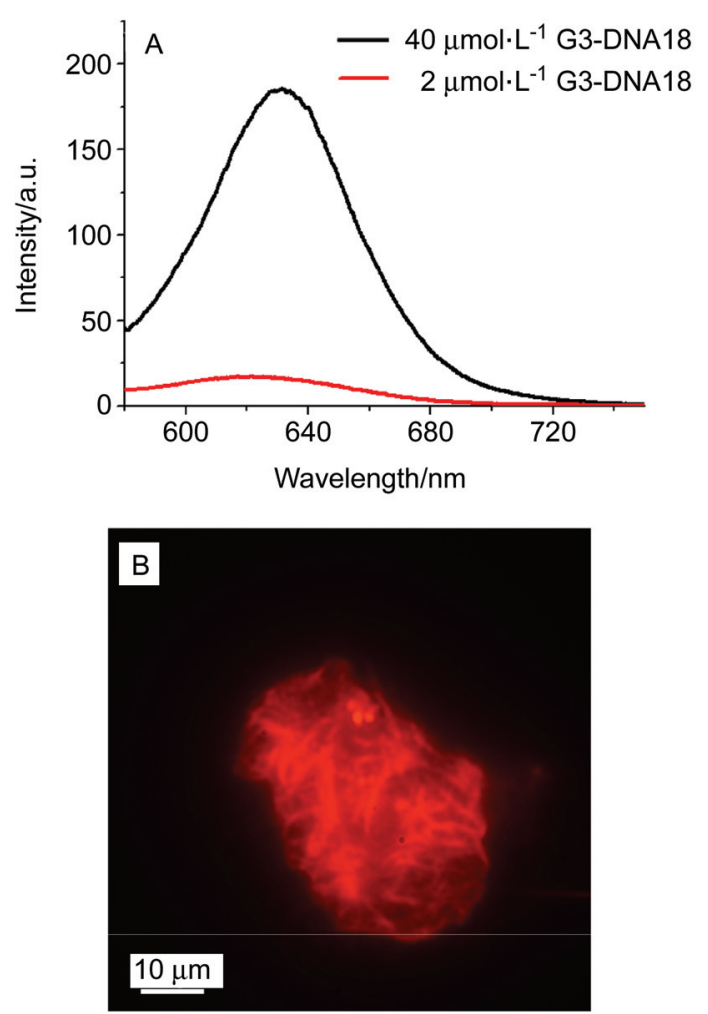

图 7 尼罗红的包裹实验. A: 分别为 $40 \mu \mathrm{mol} / \mathrm{L}$ 和 $2 \mu \mathrm{mol} / \mathrm{L}$ G3-DNA18 在水相中的荧光发射光谱; B: THF/ $\mathrm{H}_{2} \mathrm{O}(1: 10, V / V)$ 混合 溶剂中, $40 \mu \mathrm{mol} / \mathrm{L}$ G3-DNA18 纳米纤维包裹尼罗红的荧光图

Figure 7 Nile Red encapsulation experiments. A: The fluorescent emission spectra of Nile Red in aqueous solution at $40 \mu \mathrm{mol} / \mathrm{L}$ and $2 \mu \mathrm{mol} / \mathrm{L}$ G3-DNA18; B: The fluorescent image of the nanofibers from $40 \mu \mathrm{mol} / \mathrm{L}$ G3-DNA18 after Nile Red encapsulation in the THF/ $\mathrm{H}_{2} \mathrm{O}(1: 10, V / V)$ mixed solvents

其加入到纳米纤维体系中, 通过双链 DNA 的形成, 即 可将金纳米颗粒沿着细长纤维定向排列, 如图 8A. 在 对比实验中, $10 \mathrm{~nm}$ 金颗粒的表面修饰上不互补的颈基 DNA 序列(5'-CGC AAT GAC AGT ACT-3'), 则没有定 向排列, 只是随机分散, 如图 8B. 这些实验进一步证实 了之前的组装机理推测，即树枝状聚脂肪醚位于核心， 亲水的 DNA 链位于外围, 同时也说明组装体可作为金 纳米线制备的模板.

\section{3 结论}

我们合成了一类新型的柔性骨架树状分子与 DNA 的嵌段共聚物—DDA-树状聚脂肪醚杂化体, 其在不 同溶剂中能组装成不同形貌. 在水相中通过调节 DNA 序列的长度, 亲水含量降低时, 其组装形貌实现了由球 形胶束到细长纤维到三维网络结构的转变. 在 $\mathrm{THF} / \mathrm{H}_{2} \mathrm{O}(1: 10, V / V)$ 的混合溶剂中, 无论是树枝状结 构的代数变化还是亲水 DNA 序列的变化, 都不会影响 纳米纤维的形成. 进一步通过对疏水荧光分子的包裹以 及外围 DNA 配对负载金纳米颗粒的实验证实了杂化体 的组装机理, 即疏水的树状聚脂肪醚位于组装体内核,

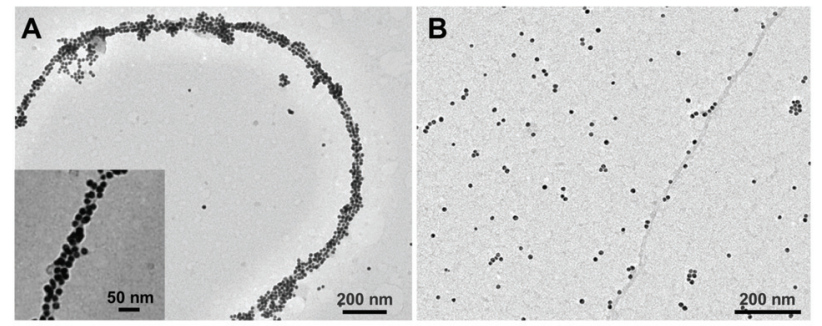

图 8 G3-DNA18 纳米纤维外围负载 $10 \mathrm{~nm}$ 金纳米颗粒的透射电镜图, (A) 互补 DNA 序列修饰的金纳米颗粒; (B) 非互补序列修饰的金纳米 颗粒. 插图为放大图

Figure 8 TEM images of the hybridization of G3-DNA18 nanofibers with $10 \mathrm{~nm}$ AuNPs containing (A) complementary ssDNA and (B) non-complementary ssDNA. Inset is the enlarged image

DNA 链作为外壳，同时也说明这类 DNA-树状聚脂肪醚 杂化体将在疏水药物包裹和纳米技术领域等具有潜在 的功能和应用.

\section{4 实验部分}

\section{1 水相中的组装条件}

将 DNA-树枝状聚脂肪醚杂化体的母液加电阻率为 $18.2 \mathrm{M} \Omega \cdot \mathrm{cm}^{-1}$ 的三纯水稀释至所需浓度 $\left(40 \mu \mathrm{mol} \cdot \mathrm{L}^{-1}\right)$, 于 $4{ }^{\circ} \mathrm{C}$ 放置过夜后, 加热至 $90{ }^{\circ} \mathrm{C}$, 保持 $30 \mathrm{~min}$, 自然 冷却回到室温, 放置过夜后测试.

\section{2 混合溶剂中的组装条件}

往 $100 \mu \mathrm{L}$ 的样品水溶液中快速加入 $10 \mu \mathrm{L}$ 有机溶剂, 振荡离心后, 于 $90{ }^{\circ} \mathrm{C}$ 加热 $30 \mathrm{~min}$ 后, 自然冷却至室温, 放置过夜后作相关测试.

\section{References}

[1] (a) Israelachvili, J. Intermolecular \& Surface Forces, 2nd ed., Academic Press, London, 1991; (b) Blanazs, A.; Armes, S. P.; Ryan, A. J. Macromol. Rapid Commun. 2009, 30, 267.

[2] Fuks, G.; Talom, R. M.; Gauffre, F. Chem. Soc. Rev. 2011, 40, 2475.

[3] (a) Gauthier, M. A.; Klok, H. A. Chem. Commun. 2008, 2591; (b) Klok, H. A. Macromolecules 2009, 42, 7990; (c) König, H. M.; Kilbinger, A. F. M. Angew. Chem., Int. Ed. 2007, 46, 8334; (d) Krishna, O. D.; Kiick, K. L. Biopolymers 2010, 94, 32; (e) Van Hest, J. C. M. Polym. Rev. 2007, 47, 63.

[4] (a) Alemdaroglu, F. E.; Herrmann, A. Org. Biomol. Chem. 2007, 5, 1311; (b) Kwak, M.; Herrmann, A. Angew. Chem., Int. Ed. 2010, 49, 8574 .

[5] Lemaitre, M.; Bayard, B.; Lebleu, B. Proc. Natl. Acad. Sci. U. S. A. 1987, 84, 648 .

[6] (a) Alemdaroglu, F. E.; Ding, K.; Berger, R.; Herrmann, A. Angew. Chem., Int. Ed. 2006, 45, 4206; (b) Zhao, Z.; Wang, L.; Liu, Y.; Yang, Z.; He, Y.-M.; Li, Z.; Fan, Q.-H.; Liu, D. Chem. Commun. 2012, 48, 9753 .

[7] Li, Z.; Zhang, Y.; Fullhart, P.; Mirkin, C. A. Nano Lett. 2004, 4, 1055 .

[8] (a) Seeman, N. C. J. Theor. Biol. 1982, 99, 237; (b) Seeman, N. C. Nature 2003, 421, 427.

[9] Costioli, M. D.; Fisch, I.; Garret-Flaudy, F.; Hilbrig, F.; Freitag, R. Biotechnol. Bioeng. 2003, 81, 535.

[10] Tong, G.; Lawlor, J. M.; Tregear, G. W.; Haralambidis, J. J. Org. Chem. 1993, 58, 2223.

[11] (a) Newkome, G. R.; Moorefield, C. N.; Vögtle, F. Dendrimers and Dendrons: Concepts, Syntheses, Applications, Wiley-VCH, Wein- 
heim, 2001; (b) Jiang, D.-L.; Sato, T.; Aida, T. Chin. J. Polym. Sci. 2001, 19, 161; (c) Li, Y.; He, Y.-M.; Li, Z.-W.; Zhang, F.; Fan, Q.-H. Org. Biomol. Chem. 2009, 7, 1890; (d) Li, P.; Zeng, Y.; Chen, J.; Li, Y.; Li, Y. Acta Chim. Sinica 2012, 70, 1611. (李鹏，曾毅，陈金平， 李迎迎, 李嫕, 化学学报, 2012, 70, 1611.)

[12] (a) Caminade, A.-M.; Turrin, C.-O.; Majoral, J.-P. Chem.-Eur. J. 2008, 14, 7422; (b) DeMattei, C. R.; Huang, B.; Tomalia, D. A. Nano Lett. 2004, 4, 771; (c) Carneiro, K. M. M.; Aldaye, F. A.; Sleiman, H. F. J. Am. Chem. Soc. 2010, 132, 679; (d) Sun, Y.; Liu, H.; Xu, L.; Wang, L.; Fan, Q.-H.; Liu, D. Langmuir 2010, 26, 12496; (e) Chen, P.; Sun, Y.; Liu, H.; Xu, L.; Fan, Q.-H.; Liu, D. Soft Matter 2010, 6, 2143.

[13] Wang, L.; Feng, Y.; Sun, Y.; Li, Z.; Yang, Z.; He, Y.-M.; Fan, Q.-H.; Liu, D. Soft Matter 2011, 7, 7187.

[14] (a) Grayson, S. M.; Fréchet, J. M. J. J. Am. Chem. Soc. 2000, 122, 10335; (b) Jayaraman, M.; Fréchet, J. M. J. J. Am. Chem. Soc. 1998, $120,12996$.
[15] Wang, L.; Feng, Y.; Yang, Z.; He, Y.-M.; Fan, Q.-H.; Liu, D. Chem. Commun. 2012, 48, 3715.

[16] Yang, M.; Wang, W.; Yuan, F.; Zhang, X.; Li, J.; Liang, F.; He, B.; Minch, B.; Wegner, G. J. Am. Chem. Soc. 2005, 127, 15107.

[17] Jeong, J. H.; Park, T. G. Bioconjugate Chem. 2001, 12, 917.

[18] Tinland, B.; Pluen, A.; Sturm, J.; Weill, G. Macromolecules 1997, $30,5763$.

[19] Cho, B. K.; Jain, A.; Nieberle, J.; Mahajan, S.; Wiesner, U.; Gruner, S. M.; Turk, S.; Rader, H. J. Macromolecules 2004, 37, 4227.

[20] Fö1rster, S.; Hermsdorf, N.; Leube, W.; Schnablegger, H.; Regenbrecht, M.; Akari, S. J. Phys. Chem. B 1999, 103, 6657.

[21] Yu, K.; Eisenberg, A. Macromolecules 1996, 29, 6359.

[22] Percec, V.; Wilson, D. A.; Leowanawat, P.; Wilson, C. J.; Hughes, A. D.; Kaucher, M. S.; Hammer, D. A.; Levine, D. H.; Kim, A. J.; Bates, F. S.; Davis, K. P.; Lodge, T. P.; Klein, M. L.; DeVane, R. H.; Aqad, E.; Rosen, B. M.; Argintaru, A. O.; Sienkowska, M. J.; Rissanen, K.; Nummelin, S.; Ropponen, J. Science 2010, 328, 1009.

(Cheng, B.; Fan, Y.) 